\title{
EFEKTIFITAS LAYANAN KONSELING KELOMPOK DENGAN TEKNIK CINEMA EDUCATION UNTUK MENINGKATKAN KEPERCAYAAN DIRI DALAIM BERWIRAUSAHA DI PANTI SOSIAL
}

\section{The Effectiveness Of Group Settlement Services With Cinema Education Techniques To Improve Self-Confidence In Enterprising In Social Beach}

\author{
'Rian hario MW, ${ }^{2}$ Heru Nurochman \\ IUniversitas Muhammadiyah Palangkaraya, Jekan Raya, Palangka Raya, Kalimantan Tengah, Indonesia \\ 2 Universitas Muhammadiyah Palangkaraya, Jekan Raya, Palangka Raya, Kalimantan Tengah, Indonesia
}

\begin{abstract}
ARTIKEL INFO
ABSTRAK

Diterima

Desember 2017

Penelitian ini bertujuan untuk: (I) Untuk mengetahui keefektifan layanan konseling kelompok dengan teknik cinema education dapat meningkatkan kepercayaan diri dalam berwirausaha peserta didik di panti bina remaja dan karya wanita. Jenis penelitian yang digunakan adalah Penelitian Eksperimen untuk mencari pengaruh atas perlakuan tertentu. Sampel dalam penelitian ini adalah remaja panti sosial bina remaja dan karya wanita 2016/2017 yang berjumlah 8 peserta didik, yang terdiri atas 8 peserta didik laki-laki. Teknik pengumpulan data yang digunakan adalah skala dan observasi. Analisis data menggunakan uji hipotesis paired sample t-test untuk menghitung perbandingan hasil rata-rata pretest dan posttest peserta didik.

Dipublikasi

Februari 2018
\end{abstract}

*E-mail:

herunurochman@gmail.com

Kata kunci: Kepercayaan Diri Dalam Berwirausaha, Layanan Konseling Kelompok, Teknik cinema education

\section{ABSTRACT}

This study aims to: (I) To determine the effectiveness of group counseling services with cinema education techniques can increase self-confidence in entrepreneurship of students in adolescent foster care and women's work. The type of research used is Experimental Research to look for influences on certain treatments. The sample in this study were adolescent social care institutions for adolescents and 2016/2017 women's works which amounted to 8 students, consisting of 8 male students. Data collection techniques used are

Orchid: scale and observation. Data analysis using hypothesis testing paired sample t-test to calculate the comparison of the results of the average pretest and posttest of students. Based on the results of the hypothesis it is known the value of sig. (2-tailed) which is 0.002 $<0.05$, which means that there is a significant difference between pretest and posttest. The pretest results showed that the average scale of students' suspensions was $8 I .13$, which was included in the category of moderate social prejudice and for the suspension of posttest scores of students, 91.75 was included in the high category. From these data shows that there is an increase in self-confidence in entrepreneurship of students after the group counseling services with cinema education techniques are implemented

Keywords: Self Confidence in Entrepreneurship, Group Counseling Services, Cinema Education Engineering 
Jurnal Bimbingan dan Konseling

\section{PENDAHULUAN}

Dunia kerja makin menjadi sempit, sementara masyarakat yang membutuhkan pekerjaan terus meningkat. Wirausaha harusnya menjadi solusi untuk mengurangi masalah pengangguran yang dihadapi oleh setiap negara. Pengangguran ini bukanlah hasil sebuah pilihan untuk tidak bekerja, tetapi akibat dari semakin sulitnya mendapatkan pekerjaan, terutama di kota-kota besar. Masalah-masalah di atas sebenarnya dapat diperkecil dengan cara berwirausaha dan menjadi pengusaha merupakan alternatif pilihan yang tepat untuk mengatasi pengangguran.

Kewirausahaan merupakan pilihan yang tepat bagi individu yang tertantang untuk menciptakan kerja, bukan mencari kerja. Kewirausahaan dimaknai sebagai semangat, sikap dan perilaku atau kemampuan seseorang dalam melihat peluang dan menangani usaha (Astuti dan Yulianto dalam Putra dkk, 2015: 4502).

Wirausahawan adalah seseorang yang mengembangkan produk baru atau ide baru dan membangun bisnis dengan konsep baru. Dalam hal ini, menuntut sejumlah kreativitas dan sebuah kemampuan untuk melihat polapola dan trend-trend yang berlaku untuk menjadi seorang wirausahawan. Namun, masih banyak yang kurang kreatif dan tidak berani mengambil resiko untuk membuka dan mengelola usaha. Kreatif dan keberanian mengambil resiko merupakan kepribadian wirausaha.

Beberapa kepribadian wirausaha lainnya seperti percaya diri, berorientasi pada hasil, kepemimpinan, kerja keras, dan masih banyak lagi, akan mendukung terbentuknya sumberdaya manusia yang mampu mengelola usaha (Aprilianty, 2012: 313)

Wirausaha merupakan salah satu pendukung yang menentukan maju mundurnya perekonomian, karena bidang wirausaha mempunyai kebebasan untuk berkarya dan mandiri. Jika seseorang mempunyai kemauan dan keinginan serta siap untuk berwirausaha, berarti seseorang itu mampu menciptakan lapangan pekerjaan sendiri, dan tidak perlu mengandalkan orang lain maupun perusahaan lain untuk mendapatkan pekerjaan lagi. Remaja sebagai salah satu penerus bangsa yang diharapkan menjadi pemimpin-pemimpin bangsa masa depan, sudah sepantasnya menjadi pelopor dalam mengembangkan semangat kewirausahaan.

Jadi berwirausaha tidak lain hanyalah salah satu cara untuk memanfaatkan kemampuan unik seseorang yang dilakukan dengan membangun, memiliki, dan menjalankan usaha (bisnis) agar dapat bermanfaat bagi diri sendiri dan masyarakat

Kewirausahaan di Indonesia belum sepenuhnya memberikan sumbangan positif terhadap kecerdasan dan kesejahteraan bangsa, padahal potensi wirausaha $\mathrm{di}$ Indonesia sangat besar hanya saja masih banyak masyarakat di Indonesia khususnya para remaja yang kurang berminat dalam berwirausaha. Minat berwirausaha ditentukan oleh kepercayaan diri dari remaja itu sendiri.

Kepercayaan diri merupakan kunci motivasi diri. Individu tidak dapat menjalani hidup dengan baik tanpa kepercayaan diri. Setiap individu akan membutuhkan kepercayaan diri setiap harinya dalam berbagai hal, termasuk remaja yang ingin berwirausaha. Tingkat kepercayaan diri yang baik memudahkan pengambilan keputusan dan melancarkan jalan untuk mendapatkan usaha, membangun hubungan dengan lingkungan, dan membantu individu mempertahankan kesuksesan.

Supriyo (2008: 44) Mengatakan bahwa "Percaya diri adalah perasaan yang mendalam pada batin seseorang, bahwa ia mampu berbuat sesuatu yang bermanfaat untuk dirinya, keluarganya, masyarakatnya, umatnya, dan agamanya, yang memotivasi untuk 
optimis, kreatif dan dinamis yang positif'. Percaya diri adalah yakin pada kemampuankemampuan sendiri, yakin pada tujuan hidupnya, dan percaya bahwa dengan akal budi orang akan mampu melaksanakan apa yang mereka inginkan. Orang yang percaya diri akan merasa cukup dengan mengetahui kemampuan dirinya dan berusaha meningkatkan kemampuan dan prestasinya tanpa menghiraukan apa kata orang. (wiranegara, 2010: 3).

Menurut Lauster (maulida \& Dhani, 2012: 3) Rasa percaya diri bukan merupakan sifat yang diturunkan (bawaan) melainkan diperoleh dari pengalaman hidup, serta dapat diajarkan dan ditanamkan melalui pendidikan, sehingga upaya-upaya tertentu dapat dilakukan guna membentuk dan meningkatkan rasa percaya diri.

Kepercayaan diri ini merupakan faktor penting yang mendorong minat individu, karena apabila individu memiliki kepercayaan diri yang kuat maka dia berani mengambil resiko menjadi wirausaha.

Berdasarkan pengertian diatas dapat disimpulkan bahwa kepercayaan diri dalam berwirausaha yaitu perasaan yakin terhadap kemampuan-kemampuan yang dimiliki, mampu melaksanakan apa yang mereka inginkan, yakin pada tujuan hidupnya dan tidak takut memulai usaha serta berani mengambil resiko menjadi wirausaha.

Dalam konseling kelompok peserta didik mampu mengembangkan diri, mengendalikan diri, dan menemukan potensi yang dimilikinya serta saling mengenal orang lain atau kelompok lain, sehingga mereka dapat berinteraksi satu sama lain dan saling bekerjasama untuk mencapai tujuan.

Konseling merupakan upaya pemberian bantuan kepada individu yang membutuhkan (konseli) yang diberikan oleh orang yang ahli dan terlatih (konselor) yang dilakukan secara tatap muka. Menurut Mugiarso (2009: 69), konseling kelompok adalah layanan konseling yang diselenggarakan dalam suasana kelompok.

Istilah konseling kelompok mengacu kepada penyesuaian rutin atau pengalaman perkembangan dalam lingkup kelompok. Konseling kelompok difokuskan untuk membantu konseli mengatasi problem mereka lewat penyesuaian diri dan perkembangan pribadi hari-ke-hari.

Contohnya, fokus kepada modifikasi perilaku, pengembangan keahlian hubungan pribadi, problem seksualitas manusia, nilai atau sikap, atau pengambilan keputusan karier. (Robert \& Marianne, 20 I I: 275).

Berdasarkan pengertian diatas dapat disimpulkan layanan konseling kelompok adalah layanan konseling yang diselenggarakan dalam suasana kelompok untuk membantu konseli mengatasi problem mereka lewat penyesuaian diri dan perkembangan pribadi hari-kehari.

Pengaplikasian layanan konseling kelompok dapat dipadukan dengan alat atau media pembelajaran, tujuannya agar peserta didik lebih tertarik dan lebih mudah untuk memahami materi yang disampaikan.

Media pembelajaran terdiri dari beberapa jenis, salah satunya adalah media audiovisual. Media ini lebih unggul daripada media yang lain. Salah satu teknik yang digunakan dalam pemberian media audiovisual yang dapat memberikan contoh untuk meningkatkan kepercayaan diri dalam berwirausaha pada remaja adalah dengan menggunakan teknik Film Edukasi (cinema education). Film Edukasi memberikan gambaran yang nyata yang mudah ditiru oleh remaja. Film memberi pengalaman kognitif dan afektif secara bersamaan bagi penontonnya. Remaja dapat membayangkan usaha dalam film yang mungkin memiliki kesamaan dengan keterampilannya. (Utami dkk, 20l4: 919)

Berdasarkan fenomena yang terjadi di lapangan, Para remaja cenderung kurang 
Jurnal Bimbingan dan Konseling

percaya diri untuk memulai usaha dikarenakan berbagai faktor seperti: Kurangnya pengalaman, Takut gagal, Malu , Lingkungan yang kurang mendukung dan masih banyaknya faktor-faktor yang dipertimbangkan para remaja sehingga menyebabkan remaja kurang berminat dalam berwirausaha. Sebagian besar remaja lebih menyukai jalan aman dari pada tantangan untuk berwirausaha, selain itu pemikiran menjadi pegawai lebih baik daripada berwirausaha salah satu faktornya, masalah psikologis itu merupakan turunan dari pemikiran para orang tua yang lebih bangga keluarganya jadi pegawai daripada berwirausaha.

Adanya fenomena tersebut faktor yang paling utama remaja enggan untuk berwirausaha adalah kurangnya kepercayaan diri remaja dalam berwirausaha. Oleh karena itu perlu adanya suatu layanan untuk meningkatkan kepercayaan diri dalam berwirausaha. Salah satu layanan dalam Bimbingan dan Konseling yang dinilai dapat mengatasi permasalah peserta didik adalah Layanan konseling kelompok.

Penelitian ini sangat penting dilakukan agar remaja lebih meningkatkan kepercayaan dirinya dalam berwirausaha dan tidak takut untuk memulai berwirausaha demi masa depannya nanti karena dengan berwirausaha individu mampu menyalurkan kreasi serta bakat yang dimilinya, serta menjadi individu yang mandiri dan dengan berwirausaha individu mampu membuka lapangan pekerjaan kepada orang lain.

Berdasarkan latar belakang tersebut maka peneliti akan melakukan penelitian dengan judul “ Efektifitas Layanan Konseling Kelompok dengan Teknik Cinema Education untuk Meningkatkan Kepercayaan Diri dalam Berwirausaha"

\section{METODOLOGI PENELITIAN}

Proses penelitian ini dilaksanakan pada bulan Maret 2017 di Panti Sosial Bina Remaja dan Karya Wanita Tahun ajaran 2016/2017. Metode yang digunakan dalam penelitian ini adalah metode kuantitatif dan jenis penelitiannya adalah penelitian eksperimen. menurut Arikunto (2006: 3) mengatakan bahwa metode eksperimen adalah suatu cara untuk mencari hubungan sebeb akibat (hubungan kasual) antara dua faktor yang sengaja ditimbulkan oleh penelitian dengan mengeliminisasi atau mengurangi atau menyisihkan fakto-faktor lain yang menggangu. Jenis metode eksperimen dalam penelitian ini adalah pre-eksperimental design dengan menggunakan one group pre-test dan post-test desigh. Penelitian yang dilaksanakan pada satu kelompok saja tanpa kelompok pembanding. Dalam penelitian ini observasi dilakukan sebanyak dua kali yaitu sebelum eksperimen dan sesudah eksperimen.

Populasi dalam penelitian ini adalah keseleruhan remaja yang ada di Panti sosial Bina Remaja dan Karya Wanita. Sampel dalam penelitian ini adalah remaja yang memiliki kepercayaan diri berwirausaha yang rendah. Teknik pengumpulan data yang dilakukan adalah:

\section{a. Observasi}

Menurut Sutriono hadi (Sugiyono, 2015: 145) mengemukakan bahwa, observasi merupakan suatu proses yang kompleks, dua diantara yang terpenting adalah proses-proses pengamatan dan ingatan.

\section{b. Skala Pengukuran}

Menurut Sugiyono,2015:93) Skala pengukuran merupakan kesepakatan yang digunakan sebagai acuan untuk menentukan panjang pendeknya interval yang ada dalam alat ukur, sehingga alat ukur tersebut bila digunakan dalam pengukuran akan menghasilkan data kuantitatif.

Teknik analisis data dalam penelitian kuantitatif menggunakan statistik. Terdapat dua macam statistik yang digunakan untukanalisis data dalam penelitian yaitu: statistik deskriptif dan statisik inferensial. Jenis 
penelitian ini adalah eksperimen menggunkan teknik analisis data statistik deskriptif. hipotesis pada penelitian ini menggunakan rumus Paired Sample T-test untuk menguji sampel dengan subjek yang sama namun mengalami dua perlakuan atau pengukuran yang berbeda

\section{HASIL DAN PEMBAHASAN}

Berdasarkan hasil penelitian yang dilaksanakan pada tanggal 31 Maret $2017 \mathrm{di}$ panti bina remaja dan karya wanita terdapat 8 peserta didik kelas Otomotif dan menjahit yang teridentifikasi kurang memiliki kepercayaan diri dalam berwirausaha yang didapat berdasarkan hasil pre-test skala .

Setelah diketahui hasil pre-test, semua peserta didik diberikan perlakuan berupa layanan konseling kelompok dengan teknik cinema education pada peserta didik. layanan konseling kelompok dilakukan sebanyak delapan kali pertemuan dengan waktu sebanyak I x 90 menit per minggunya. Setelah layanan dilakukan, terjadi perubahan tingkat kepercayaan diri dalam berwirausaha pada peserta didik yang diketahui dari hasil lembar refleksi,diskusi dan observasi peserta didik.

Hasil pretest menunjukkan bahwa skors rata-rata skala peserta didik yaitu 81,13 yang dimana angka tersebut termasuk dalam kategori sedang dan untuk skors rata-rata posttest peserta didik yaitu 9/,75 termasuk dalam kategori tinggi.

Dari data tersebut menunjukkan bahwa adanya peningkatan kepercayaan diri dalam wirausaha peserta didik setelah dilaksanakan layanan konseling kelompok dengan teknik cinema education.

\section{KESIMPULAN}

Layanan konseling kelompok dengan teknik cinema education efektif untuk meningkatkan kepercayaan diri dalam berwirausaha peserta didik dan hasil rata-rata pretest dan posttest memiliki perbedaan yang cukup signifikan.

\section{DAFTAR PUSTAKA}

Arikunto Suharsimi, 2006. Prosedur Penelitian suatu pendekatan praktik. Jakarta: Penerbit Rineka Cipta.

Aprilianty, Eka. 2012. Pengaruh kepribadian wirausaha, Pengetahuan Kewirausahaan, dan Llingkungan Terhadap Minat Berwirausaha Siswa SMK. Anterior Jurnal, 2, 3II - 324

Gibson, Robert L dan Marianne H. Mitchell. 20II. Bimbingan dan konseling. Yogyakarta: Pustaka Pelajar.

Mugiarso, Heru. 2009. Bimbingan dan Konseling. Semarang: UPT Unnes Press

Sugiyono, 2015. Metode Penelitian Kuantitatif kualitatif dan $R$ \& $D$. Bandung: Penerbit Alfabeta

Supriyo, 2008. Studi Kasus Bimbingan Dan Konseling . Semarang: Nieuw Setapak.

Utami, dkk, 20l4. Efektifitas cuplikan sinema edukasi untuk meningkatkan ketrampilan pemecahan masalah bagi siswa smp Anterior Jurnal 9: 91 7-926

Wiranegara, 2010. Total Sefl-Confidence. Yogyakarya: New Diglossia. 